\title{
States and Refugee Integration: a Comparative Analysis of France, Germany, and Switzerland
}

\section{Scott Feinstein ${ }^{1} \mathbb{D} \cdot$ Cristina Poleacovschi $^{2} \cdot$ Riley Drake $^{3} \cdot$ Leslie Ann Winters $^{4}$}

Accepted: 18 December 2021 / Published online: 7 January 2022

(c) The Author(s) 2022

\begin{abstract}
The Syrian civil war led to mass migration and Europe becoming a potential site of refuge. How have Syrians experienced refuge in Europe? Drawing on 58 interviews with Syrian refugees in Germany, France, and Switzerland, we find that refugees continue to experience exclusion in all integration domains including those found as markers and means, social connections, facilitators, and foundations of integration . While our cases demonstrate that Syrian refugees in Europe experience discrimination across all domains, not all conditions are equal. Using narrative analysis, differences were observed within three integration domains. Accessing language programs was more challenging in France, finding housing was more challenging in Germany, and F type residence permits limited refugees' rights in Switzerland more than in other countries. Discrimination across domains is deepening the socio-cultural-economic divide between autochthonous communities and Syrian refugees, but not all domains are equally divisive across countries. The findings outline that where these states outsourced refugee services, refugees experienced increased barriers to integration.
\end{abstract}

Keywords Integration domains · Syrian refugees · Germany $\cdot$ Switzerland · France

Scott Feinstein

sgfeinst@iastate.edu

Cristina Poleacovschi

poleacov@iastate.edu

Riley Drake

rdrake@iastate.edu

Leslie Ann Winters

winters1@iastate.edu

1 Department of Political Science, Iowa State University, 539 Ross Hall, Ames, IA 50011, USA

2 Construction and Environmental Engineering Department, Iowa State University, Town Engineering Building, 402 Town Engineering, Ames, IA 50011, USA

3 Department of Family Studies, Iowa State University, 1720A Lagomarcino Hall, Ames, IA 50011, USA

4 Department of Education, Iowa State University, 4380 Palmer, Ames, IA 50011, USA 


\section{Introduction}

The ongoing conflict in Syria since 2011 has produced a mass exodus of people seeking refuge in neighboring countries. In 2015 alone, hundreds of thousands of Syrians made their way to Europe. For all these refugees to thrive, it was critical that they became integrated (Ager \& Strang, 2008; Mestheneos \& Ioannidi, 2002). Broadly, integration is the strategy that refugee and autochthonous populations undergo in accepting cultural diversity and promoting equitable participation under one political system (Berry, 2011). The process of accepting cultural diversity means that both the refugee and autochthonous population take a strategy to maintain a degree of cultural integrity while also participating in society. In addition to both populations having an interest in this strategy, there must be opportunities to maintain culture and participate in society. The literature makes it clear that the integration strategy depends heavily on the opportunities made available to refugees (OECD, 2016). Accessing these opportunities can be a challenge, as Europe's Syrian refugees have, while seeking asylum, experienced substandard housing conditions, limited healthcare, and significant legal challenges (van Heelsum, 2017). The restricted access to diverse opportunities limits refugees' ability to build social bonds in their own communities, limiting the maintenance of cultural integrity, and the host communities, limiting participation in society (Ward et al., 2020). These economic, social, and legal opportunitiesreferred to as domains of integration (Ager \& Strang, 2008)_-include the following: markers and means (employment, housing, education and health), social connection (social bonds, social bridges, and social links), facilitators (language and cultural knowledge, safety, and stability), and foundation (rights and citizenship).

While research on domains of integration is on the rise, studies tend to focus on domains through a siloed lens, often focusing on one domain of integration at a time. Some studies focused on the policies and means that facilitate refugees' inclusion in a specific domain (Ward et al., 2020; Valenta \& Bunar, 2010) or the experiences of refugees in a specific domain (Ager, 2014; Hart, 2014; Sigona, 2014;). Other studies have focused on specific markers and means domains, such as housing (Bakker et al., 2016), economic integration (Bevelander, 2016), or employment (Andersson et al., 2018; Cheung \& Phillimore, 2014; Luik et al., 2018). As such, there continues to be a dearth of research on integration across multiple or all domains. Indeed, Katharine Donato and Elizabeth Ferris (2020) identify only three studies that examined refugee integration across multiple domains (Beversluis et al., 2016; Phillimore $\&$ Goodson, 2008; Puma et al., 2018). The rationale for studying integration across multiple domains is based on the fact that refugees are not integrated unless they are provided with opportunities and equitable resources in all spaces of society (Ager $\&$ Strang, 2008). For instance, integration cannot be successful if refugees are provided adequate housing but not equal civil rights. A multi-dimensional approach to integration addresses this issue and provides a more careful and accurate analysis of factors affecting refugees' experiences.

Furthermore, integration studies conducting cross country comparative analyses of refugee integration across multiple domains is absent, to our knowledge 
no studies have employed one before (Donato \& Ferris, 2020; Collier \& Betts, 2017; Fiddian-Qasmiyeh et al., 2014, 13). A cross country comparative analysis helps identify patterns of similarities and differences and generalizes these patterns beyond a single country. Cross country comparisons are also useful in increasing the validity of the identified patterns as they keep several structural factors accounted for (e.g., OECD states), helping isolate causal factors that may be affecting integration.

In addressing the need for comparative studies on multiple integration domains, the current research poses the following question: How have Syrian refugees experienced integration in cities in Germany, France, and Switzerland across integration domains? We find that despite the rise and prevalence of discrimination over the last half decade in Europe, as evidenced by public opinion polls and the rise of antiimmigrant populist parties (Bermúdez, 2020), countries vary in the severity of discimination across integration domains. Our initial findings in these three countries demonstrate that when integration domains are primarily serviced by private organizations, access to opportunities for integration is less likely than when serviced by public organizations.

\section{Integration Theories}

One key concept that has emerged in the resettlement of refugees is that of integration. Several scholars have tried to define what successful integration looks like for a refugee. In doing so, authors have widely contested what integration means. Harrell-Bond (1986) defined it as a place of co-existing for refugee and host communities and a sharing of resources with no greater mutual conflict. Yet, Harrell-Bond soon saw his definition as too simplistic. The definition did not, after all, address the fact that refugees could be marginalized and still receive unequal resources, or may be exploited. Similarly, Wijbrandi (1986) measured integration as the opposite of marginalization - activities refugees engage in that generate income and elevate their social and economic status in the local population. Consistent across these concepts is the process of marginalization from diverse aspects of the life. The process of marginalization represents providing unequal opportunities by impeding access and participation or providing unjust opportunities. In line with Berry's model (e.g., assimilation, separation, integration, and marginalization) (Berry, 1992) that discusses the process of integration as related to identity and cultural affiliation during participation, we focus on the access to opportunities to participate. Importantly, refugees can adopt the culture of the host community while also maintaining their own culture only while they have access to opportunities and resources. Nevertheless, integration as a form of participation is not unidimensional. Kuhlman (1991) offered a detailed representation of integration as touching on every domain of life. He wrote that:

If refugees are able to participate in the host economy in ways commensurate with their skills and compatible with their cultural values; if they attain a standard of living which satisfies culturally determined minimum require- 
ments (standard of living is taken here as meaning not only income from economic activities, but also access to amenities such as housing, public utilities, health services, and education.); if the socio-cultural change they undergo permits them to maintain an identity of their own and to adjust psychologically to their new situation; if standards of living and economic opportunities for members of the host society have not deteriorated due to the influx of refugees; if friction between host population and refugees is not worse than within the host population itself; and if the refugees do not encounter more discrimination than exists between groups previously settled within the host society: then refugees are truly integrated (p. 7).

Kuhlman suggests that participation can happen in multiple domains including those Ager and Strang (2004) theorized and detailed in an integration framework (Platts-Fowler \& Robinson, 2015).

Ager and Strang (2004) are highlighted for their theory of integration and detailed framework of integration domains (Platts-Fowler \& Robinson, 2015). Those domains fall under four integration factors-markers and means, social connection, facilitators, and foundation. Markers and means focus on the functional domains that are markers of being integrated: employment, housing, education, and health (Platts-Fowler \& Robinson, 2015). Social connection refers to social bonds, social bridges, and social links. These domains focus on connections within the refugee community, bridges formed to other groups, and links to societal resources (PlattsFowler \& Robinson, 2015). Facilitators focus on domains that help refugees successfully engage in society, skills that entail language and cultural knowledge, and safety and stability. Lastly, the foundation of integration focuses on the domain of rights and citizenship (Platts-Fowler \& Robinson, 2015). A growing number of researchers have called on scholars to conceptualize integration as a multidimensional process in which refugees' inclusive participation in diverse domains is critical for their quality of life and maintaining their new and original culture (Borselli \& van Meijl, 2020; Phillimore, 2020; Ward et al., 2020). This article responds to these scholars' call and employs a multidimensional analysis of integration which builds on the understanding that each refugee lives and functions in all domains. In doing so, we view each refugee as a person with multiple integration experiences that have an additive effect on their lives (Hairo et al., 2019). For instance, the economic outcomes they achieve are argued to be dependent upon the integration a refugee experiences in educational, social, and cultural domains (Hynie, 2018). In addition to our multidimensional analysis, this article compares these domains of integration across three European states. By comparing each domain across European states, we identify more generalizable patterns of integration and effective sources of integration. While work has been done comparing integration across countries, to our knowledge, the vast majority of this work focuses on economic integration and does not comparatively examine multiple domains (Donato \& Ferris, 2020). In some cases, scholars examine non-economic domains but they typically focus on a single domain or aspects within a domain (for example: education (McBrien, 2005); social capital (Wijers, 2013; Daley, 2007) health and psychology (Matlin et al., 2018; Knipscheer et al., 2015; Nelson-Peterman et al., 2015; Takeda, 2000); discrimination (Te 
Lindert et al., 2008; Lindert et al., 2008); disability (Mirza, 2012); and citizenship rights (Baban et al., 2017). By examining multiple domains in a comparative perspective, our research takes a holistic view of contemporary integration of Syrian refugees in Europe.

\section{Markers and Means}

Employment is important to refugees. It allows them an opportunity to learn the language, build a future, regain confidence, and establish status. What is especially critical in gaining employment for refugees is human capital. It increases the opportunity to learn and practice the language of their host country. Human capital theory proposes that having job-related skills and academic qualifications increases one's chances of being employed (Gracia et al., 2016; Barone et al., 2011). Particularly, language proficiency, a highly valued skill, is critical for finding employment among first-generation migrants (Van Tubergen \& Kalmijn, 2005; Chiswick \& Miller, 1999). By the same token, lacking language proficiency can lead to negative representation in the media and a refusal by the hiring organization to recognize prior credentials (Jackson \& Bauder, 2013; Tomlinson, 2010; Ager \& Strang, 2008; Bloch, 2004; Dumper, 2002; ECRE, 1999).

Another domain of integration is housing. Securing housing, an important step to gaining social inclusion, is considered a precondition to enjoying basic rights and services (Andersen et al., 2013; Netto, 2011; Phillips, 2006). Housing also has an effect on the physical and emotional well-being of refugees (Ager \& Strang, 2008). For refugees, the place they live is not just about location, it also influences their feelings and impacts on the quality of their experiences in that space (Cloke et al., 2005). Hence, when a community's housing policies are inadequate, this raises a barrier for refugees (ECRE, 1999). In fact, they can result in increased experiences with discrimination and spatial segregation (Buscher, 2011; Jacobsen, 2006; Landau, 2006).

A vital part of integration is education. Attending a school provides displaced individuals a sense of normalcy, allows for socialization, and even instills hope (Mosselson et al., 2017). From receiving education, a refugee is apt to build relationships and become a productive member of society. Some barriers faced by children entering school are isolation and exclusion, inexperience in how to navigate the school system, and improper support for learning the host country's language (Ager \& Strang, 2008). In a study conducted by Rabia Hos (2020), the author found that refugee children in the United States whose education had been interrupted needed social and emotional support, had additional responsibilities at home to worry about, and did not know enough about the education system to create realistic career goals. These previous studies outline not just the importance of education for integration but also the challenges in accessing and obtaining it.

Finally, possessing good health is viewed as a condition for active engagement in a new society. Barriers to refugees' health revolve around accessibility to health care. Power differentials in the doctor-patient relationship can make it difficult for refugees to trust their doctors (Newbold \& McKeary, 2016), and language barriers 
can hinder communication (Shirazi \& Caynan, 2016). If refugees are able to share their stories and journeys with doctors, then they will engage more, which ultimately can improve their health (Newbold \& McKeary, 2016; Shirazi \& Caynan, 2016). Being able to communicate effectively is also key to refugees providing their medical history. Having good translation services then is critical but not sufficient, as it takes time for a refugee to build trust in both the translator and the doctor (Shirazi \& Caynan, 2016).

According to several studies, when newcomers are excluded or rejected by a host community, mental health issues are often a result (Whittaker et al., 2005; Sinnerbrink et al., 1997). In fact, a major concern is posttraumatic stress disorder (PTSD) (Beiser, 2009; Silove et al., 2007; Blight et al., 2006; Keller et al., 2006; Beiser \& Wickrama, 2004; Mollica et al., 1997). PTSD can be augmented by the language barrier, a lack of information about services, and the legal frame of the host country (Lindert et al., 2008). Mental health and trauma can differ among migrant groups, none of which is properly addressed when migrants try to access care (Robila, 2018).

\section{Social Connection}

A necessary component of new migrants settling into local areas are social connections with the settled population. The three primary forms of social capital that refugees can build are bonding, bridging, and linking social capital (Woodlcock, 2002; Kawachi, 2006; Poortinga, 2012; Tippens, 2019). All three are important to refugee health and well-being (Szreter \& Woolcock, 2004). Those who share similar attributes and social identities can generate bonding social capital (Tippens, 2019). Bonding social capital is necessary for social cohesion and support (Poortinga, 2012). Social bonds also refer to the trust and co-operative relationships between people who share cultural practices and social identities (Ager \& Strange, 2008; Hogg, 2006). While social bonds are important in the integration process, creating these bonds in the refugee community can be influenced by the makeup of the local population and the mobility of the refugee population (Platts-Fowler \& Robinson, 2015).

Bridging capital signifies the connections between people who are different regarding social identity (Kawachi, 2006). It is representative of external social networks across different social and ethnic groups who do not share similar identities (Poortinga, 2012). Building social bridging capital to another community can depend on community norms and values related to shared identities, history of treatment due to differences, and the shared understandings between different groups (Platts-Fowler \& Robinson, 2015).

Linking social capital is best described as the norms of respect within trusted relationships that interact across power hierarchies in society (Kawachi, 2006; Poortinga, 2012). Power hierarchies could include local authorities, job centers, political resources, or any local organizations where citizen rights are exercised (PlattsFowler \& Robinson, 2015). Linking social capital can provide valuable resources and rights for refugees, though its availability is not equitable. Gender plays a key 
role; female refugees tend to easily access bonding capital but struggle to access linking and bridging capital (Boateng, 2010; McMichael \& Manderson, 2004).

\section{Facilitators}

For refugees to establish a sense of belonging in a new society, one of the most vital factors is proficiency in the host language. Considered a gateway, language can secure employment and social connections (Kristjansdottir \& Skaptadottir, 2018). When refugees lose their social connections, they can experience stress, loneliness, and sadness (Kristjansdottir \& Skaptadottir, 2018; Wachter et al., 2016; Pedersen, 2012; Deacon \& Sullivan, 2009). Additionally, if a refugee lacks these second-language skills, he or she is unequipped to fight for rights, resulting in further exclusion ( Akcapar \& Simsek, 2018; Grace et al., 2018). Another facilitator of belonging is access to safe environments (Platts-Fowler \& Robinson, 2015). For refugees, safe environments include not being discriminated against, feeling personally safe, and sensing peace between communities. Refugees want to live in areas that are well regarded as it provides them with a feeling of safety. They would engage in their local communities if they believed the communities were free from physical threats, fear, and abuse (Ager \& Strang, 2004).

\section{Foundation}

The foundation to understanding the integration of refugees is rights and citizenship (Ager \& Strang, 2008). While notions of nationhood, rights, and citizenship may vary by location, they are necessary to understanding the integration process (Strange \& Ager, 2010). They shape the fundamental understanding of the rights rendered to and responsibilities expected of refugees (O'Neill, 2001). An articulation of refugee rights can thus describe the foundation of integration policy that refugees may expect host governments to uphold (Ager \& Strang, 2008).

\section{Methods}

This research included interviews with 58 Syrian refugees living in Germany, France, and Switzerland. Conducted during the summer and fall of 2019, the interviews enlisted respondents representing a range of demographics and attributes, including gender, employment status, family status, language proficiency, and age.

We examined these three countries for their comparative leverage as they account for the numerical impact of Syrian refugees on integration. As of 2019, Germany had the greatest number of Syrian refugees $(\sim 572,000)$ in Europe, and France and Switzerland have roughly the same number of Syrian Refugees $(\sim 18,000)$. However, Syrian refugees, as a percentage of the population in each country, represented a different mass - Germany $0.68 \%$, France $0.03 \%$, and Switzerland $0.22 \%$. From the ten European countries that hosted most Syrian refugees, Germany, France, and Switzerland roughly, and respectively, represent the highest, lowest, and median number 
of Syrians refugees as a percentage of the population. ${ }^{1}$ Comparing countries with a different percentage of Syrian refugees helped our study to account for the net influx of Syrians. The numbers were important as they are often related to the level of popular anti-immigration and anti-integration perceptions (Bonikowski, 2016). Accounting for the number of refugees was then helpful to discern causality. Differences across countries could potentially be related to the number of refugees and similarities and differences across countries could help point to broader preexisting conditions in Europe.

The recruitment, primarily conducted by the researchers and the translator, selected interviewees through snowballing techniques in six cities: Berlin, Essen, Bochum, Reims, Paris, and Zurich. Each city is notable for its large Syrian refugee populations. The translator who is himself a refugee helped identify an initial group of family and friends who helped recruit the remaining participants. To obtain a comprehensive understanding of the challenges experienced by Syrian refugees, the translator aimed to identify a diverse group of respondents in terms of their age and gender (Table 1). To be eligible, respondents had to be at least 18 years old and identified as a Syrian refugee. The interviews were conducted either by the translator or by the researchers with the help of the translator. The translator, a journalist, was a young Syrian refugee living in Italy. Semi-structured interviews were conducted face to face and lasted from $30 \mathrm{~min}$ to two hours. The interview protocol included open-ended questions intended to identify respondents' everyday experiences including challenges in all domains. Interviews were, per institutional review board guidelines, conducted in a private setting. Respondents were asked questions regarding their experiences during the resettlement process, such as the following: "Can you please tell me about your journey to Europe?" "What are the issues that are the most important for you?" "In what ways have you been involved with solving the issues that you consider as important for you?" The interviews were then transcribed and translated by a professional translator.

For data analysis, the research used a combination of narrative analysis and a consensual qualitative research (CQR) approach. Narrative analysis included identifying themes in the data based on recurring ideas. A theme represented a challenge that numerous refugees mentioned in talking about the process of integration. These themes were inductively coded under the deductive framework within the domains of integration. To increase the reliability of the data analysis, researchers used the CQR as a second step. They identified themes and discussed them verbally and in writing. The process was conducted with the goal of reaching consensus on the identified themes. The researchers met on a weekly basis, approximately ten times, to discuss the coding and revise the coding framework before reaching consensus on the themes. The consensual qualitative research is important in order to avoid groupthink; it also allows inclusion of diverse perspectives in the coding process.

\footnotetext{
${ }^{1}$ Of the ten European countries with the most Syrian refugees, Syrian Refugees make up a specific percentage of the population: Sweden $(1.12 \%)$, Germany $(0.68 \%)$, Austria $((0.58)$, Denmark $(0.35 \%)$, Greece $(0.26 \%)$, Bulgaria $(0.25 \%)$, Switzerland $(0.22 \%)$, Netherlands $(0.18 \%)$, Belgium $(0.14 \%)$, France (0.03\%) (UNHCR, 2019).
} 
Table 1 Interviewee demographics

\begin{tabular}{|c|c|c|}
\hline Demographic characteristics & Category & $\begin{array}{l}\text { Percentage of } \\
\text { respondents } \\
\text { (\%) }\end{array}$ \\
\hline \multirow[t]{3}{*}{ Country of residence } & Germany & 46 \\
\hline & Switzerland & 19 \\
\hline & France & 35 \\
\hline Religion & Muslim & 100 \\
\hline \multirow[t]{4}{*}{ Language proficiency } & Arabic & 100 \\
\hline & German & 56 \\
\hline & English & 19 \\
\hline & French & 13 \\
\hline \multirow[t]{2}{*}{ Relationship status* } & Married & 19 \\
\hline & Single & 56 \\
\hline \multirow[t]{2}{*}{ Gender } & Female & 19 \\
\hline & Male & 81 \\
\hline \multirow[t]{3}{*}{ Age } & Under 25 & 19 \\
\hline & Between 25 and 50 & 78 \\
\hline & Over 50 & 3 \\
\hline \multirow[t]{2}{*}{ Ethnicity } & Arab & 97 \\
\hline & Kurdish & 3 \\
\hline \multirow[t]{3}{*}{ Year of entry } & 2003-2013 & 21 \\
\hline & 2014-2015 & 55 \\
\hline & 2016-2018 & 24 \\
\hline \multirow[t]{7}{*}{ Means of entry } & Smuggler & 33 \\
\hline & Student Visa & 14 \\
\hline & Unspecified & 15 \\
\hline & Family reunification & 8 \\
\hline & Travel Visa & 12 \\
\hline & Asylum refugee visa & 6 \\
\hline & Other & 12 \\
\hline
\end{tabular}

$* 25 \%$ of respondents did not specify

\section{Results: Exclusion from Domains of Integration in France, Switzerland and Germany}

\section{Markers and Means}

Employment Excluded from the same opportunities afforded to autochthonous populations, Syrians were primarily allowed to participate in the low-wage economy. Regardless of an individual's experience and education, many refugees in all three countries reported being systematically barred from high-wage positions and even general employment based on their age, nationality, or religion. Refugees recounted their attempts to secure employment but being denied because of their nationality or 
their foreign-sounding names: "if there is a Swiss and a refugee with the same possibilities, the company decides to hire a Swiss." Similarly, a refugee with higher education and proper training in France described submitting 30 applications for jobs at local pharmacies and all of them being rejected. Another form of exclusion for highwage positions included religion and gender. Women who wore hijabs were routinely rejected for employment. Stories about job rejection were frequent among refugees in all three countries. Refugees reported that the one formal mechanism that impeded their access to high-wage employment was government agencies refusal to recognize their professional licensure and education. Many refugees were forced to change their professions and work in sectors incompatible with their training and education. With that professional history going unrecognized, they felt a devaluing of their previous life experience. For those refugees who did attempt to gain the necessary recognition to practice their profession, local governments required extensive coursework, examinations, and lengthy time periods of supervision. Unfortunately, not all refuges were able to commit the time needed to access and attend these educational opportunities.

Being excluded from the formal economy, refugees struggled to integrate and normalize in multiple domains of integration. These institutional (formal rules and norms limit behavior and access to opportunities) and intentional (individual's limit behavior and access to opportunities) discriminatory practices enforce an economic class division that maps onto a social and perceived cultural distinction between the autochthonous and refugee populations. Being a refugee in Europe not only resulted in unequal employment opportunities that limited economic participation, but it directly limited Syrian refugees' opportunities to participate in wider social and cultural activities, like attending community events or taking in a local art exhibit. Being underpaid exacerbated refugees' struggle to escape poverty, limited their participation in society, and left them little time to act or be seen as a part of the community. For instance, without a disposable income, many refugees described being priced out of cultural activities and not having sufficient time to participate in community activities and events. Economic inequalities also furthered status distinctions that limited the potential to be seen as an equal or natural participant in community activities. As employment discrimination constrains disposable income and time, Syrian refugees remain socio-economically separated from European nationals (Fasani et al., 2018; Luik et al., 2018).

The socio-economic gap separating Europeans and Syrian refugees was only widened by the relative success refugees found in undocumented employment and remuneration, that is, in the informal economy. With minimal access to high-wage jobs, refugees found incentive to work in the informal economy. Refugees acknowledged that they found work "illegally," meaning that they worked for an employer without official documentation. In these instances, employers often exploited refugees, paying them very low wages and dismissing them without notice. Despite these negative experiences, many refugees were still attracted to the informal economy and remained unemployed, as with that status they often received larger government payments. They reported that the pay from jobs in the formal economy was insufficient to cover living expenses. Hence, many refugees were compelled to remain unemployed, so as to avoid the economic fall their families would experience 
Table 2 Monthly cost of living v. monthly state assistance

\begin{tabular}{lll}
\hline Cities & $\begin{array}{l}\text { Cost of living } \\
\text { (Euro) }\end{array}$ & $\begin{array}{l}\text { State assistance } \\
\text { (Euro) }\end{array}$ \\
\hline Berlin & 1,899 & 354 \\
Essen & 1,390 & 354 \\
Bochum & $1,238^{*}$ & 354 \\
Reims & 1,441 & 204 \\
Paris & 3,400 & 204 \\
Zurich & 3,582 & $1,045^{* *}$ \\
\hline
\end{tabular}

Cost of living was identified through Expatistan (2021), except for Bochum*, which was found on Numbeo (2021). State assistance was identified through Hodali and Prange (2018), except for Zurich**, which was found on Asylum Information Database (2021)

if they did gain employment and forgo government subsidies. If refugees remained unemployed, they were more likely to rise above subsistence living, but at the cost of participating in the traditional economy and navigating its challenging path to integration. Generally, these countries do not suffer from high unemployment rates. Unemployment rates range from around $10 \%$ in France to $6 \%$ in Germany and $4 \%$ in Switzerland (OECD, 2021). High employment appears to prevail primarily in refugee communities.

Table 2 illustrates the cost of living compared to state assistance. While refugees mention that the state assistance is often a vital part of their income, it is far below the cost of living in every city where we interviewed refugees.

Housing Refugees noted that finding and maintaining stable housing was an overwhelming and time-intensive endeavor especially in Germany and Switzerland. In Germany, the majority of refugees mentioned challenges in finding housing because of the private landlords making housing allocation decisions. Landlords preferred refugees who were employed and were not receiving any form of social benefits or assistance from the government. Forced to have employment before residence was challenging for newcomers who needed time to find employment. Many landlords refused to rent housing to Syrian refugees. One refugee mentioned being told blatantly that he would not be provided an apartment because he was Syrian: "You are Syrian and therefore I will not give you the apartment. A German citizen deserves this apartment more than you." To avoid landlords, refugees tried finding apartments through German friends or by using brokers. Brokers were helpful but not accessible to all as they were very expensive (e.g., 5000 euro). When an apartment was out of reach, refugees would consider moving to other regions but here again they faced challenges. The German government prohibited moving from one city to another before refugees' 3-year residence permit expired. The German government also had limitations on the space allocation for apartments. One refugee described this process: 
A refugee is obliged to go to his or her permanent staff member to submit applications or obtain the necessary approvals for anything, even if it is marginal, or if the refugee has found a house for rent, which is bigger than 50 meters (for one person), the employee refuses because he does not meet the rent requirement of the government. Even if the house is cheap, he or she rejects the application.

Whether the means to housing in Germany were private or public, refugees encountered tremendous difficulty. The difficulty in finding housing in some areas often creates settlement communities where housing is more available (Fennelly \& Palasz, 2003; Zhou \& Bankston, 1998), isolating refugees from the autochthonous population and social bridging networks that can facilitate integration (Murdie and Ghosh, 2009) and empowerment (Feinstein \& Poleacovschi, 2021).

In Switzerland, refugees described a two-way process to finding an apartment. Some found apartments with the help of the refugee office or they searched on their own through private landlords. Whether one chose the public or private option was largely determined by their residence permit. Those with an F-residence permit had little choice but to go through the refugee office as many landlords refused to provide an apartment. The majority of the refugees who were provided with an apartment through the refugee office mentioned being satisfied with this process. Some did complain about the quality of certain apartments or about not having the opportunity to choose an apartment. Refugees with a B-residence permit could choose their apartment, but noted two challenges. They experienced a similar discriminatory process as observed in Germany where landlords favored Swiss nationals or other Europeans. Additionally, they noted that social benefits provided by the government were insufficient; with the meager assistance provided, they could not pay the full rent.

In France, refugees were generally satisfied with the government-provided services for finding an apartment. The government provided social housing and worked closely with real estate agencies in finding them. Unlike in Germany and Switzerland, refugees found housing quickly primarily because landlords did not participate in the approval process. Delays in the approval were still common in urban areas such as Paris and Lyon where the demand was higher and the process was longer. Refugees in France still noted some negatives to social housing such as being located in an isolated section or on the outskirts of the community. This segregation from the rest of the community resulted in an inability to build relationships with community members, and an overreliance on one another. A refugee in France mentioned that this exclusion negatively affected their integration and quality of life:

The government gathers all foreigners in one region or one neighborhood. The government thus impedes the integration process, as it cuts communication between the French and immigrants. This also increases crime because the government neglects neighborhoods inhabited by refugees or migrants. This thing is happening everywhere in France. 
Being segregated from the host community only further alienated refugees from French residents. Refugees recounted how this practice seemed to bolster existing stereotypes about themselves and make their conditions more hostile.

The housing market clearly varies across cities. Table 3 in the appendix lists the monthly average rates for renting apartments in each of the six cities (Numbeo, 2021). Unsurprisingly, the cost of housing in Berlin, Paris, and Zurich are the most expensive with three-bedroom apartments in the city center averaging roughly 20004000 Euro per month and one-bedroom apartments in the city center averaging 1000-2000 Euro per month. The cost of housing in Essen, Bochum, and Reims are less expensive with three-bedroom apartments in the city center averaging roughly 900-1300 Euro per month and one-bedroom apartments in the city center averaging 500 Euro per month. The larger cities face more competitive markets, which aligns with our results on housing in Berlin. Unlike other cities, refugees mentioned Berlin housing market as being particularly competitive.

For Syrian refugees housing discrimination had two salient effects-the blocking of assimilation (adopting the cultural norms of the autochthonous population (Berry, 1992)) and the forsaking of their home culture. First, those unable to secure adequate housing were unable to assimilate and actively "othered." Without a house to live in, a refugee could not begin to feel a sense of home. In this study, densely populated areas frequently had insufficient housing. To secure housing, refugees were forced to find a sublease or wait for extensive periods. Some refugees had no choice but to live in shelters or move into housing with other refugees in substandard conditions. Finding homes large enough to comfortably accommodate large families was nearly impossible. In urban areas, even refugees without families had to wait for years to secure housing. In other words, these refugees went years with no opportunity to look like, or feel included with, the vast majority of those living in the country. Lastly, even when provided with housing, refugees in all three countries were barred from bringing their culture into it or were allowed to live only in allimmigrant neighborhoods. Landlords imposed discriminatory restrictions, such as dictating that the tenant could not play Arabic language television channels or Arabic music. Without their music, television, and attire, refugees were allowed only a physical shelter but not a home in the traditional sense. Those who obtained shelter became divided, as they were prohibited from participating, even in private, in all their cultural traditions, which made it difficult for them to integrate. In order for them to have housing, it would seem they must abandon their cultural practices.

The comparison across cases demonstrated that public led housing in France outperformed the private led housing in both Germany and Switzerland. When refugees were assisted through government services and could avoid encountering private landlords, they were able to find adequate housing at a satisfying rate.

Education In all three countries, the most central issue regarding education concerned the respective governments recognizing Syrian university degrees and licenses. "The government does not help Syrian refugees and university students to study in Switzerland. For example, the Swiss government does not recognize Syrian university degrees. The government doesn't take proper care to help them." Syrian refugees were not able to practice their professions unless they underwent a 
time-consuming, costly, and laborious process of meeting the settled community's standards for their particular profession. They described cumbersome and lengthy processes where refugees had to enroll in additional classes and pass examinations. For example, medical and pharmacy practitioners had the opportunity to enroll in a three-year program and participate in practical training at a pharmacy school and receive a certificate at the end of it. Nevertheless, the certificate was not as valuable as a university degree. Therefore, refugees had to still enroll in the university to obtain full credentials. Refugees who had the time and resources to attend a university were generally satisfied with the quality of university programs and the fact that university was mostly free. For many refugees, though, their waking hours were consumed trying to secure employment and housing. As such, they did not see educational opportunities as viable.

All three countries have the same basic university enrollment requirements and no legal restrictions preventing refugees who have not obtained asylum. While the application process is fairly uniform, there is a separate admission process for those who graduated in a foreign state outside the European Union. There is an investigation as to whether their degree(s) are equivalent to an accredited higher education qualification (Grüttner et al., 2018). Furthermore, many found challenges navigating the application process, obtaining language proficiency, and finding sufficient resources to forgo employment and attend university. Beyond these informal restrictions, family obligations and the need to seek employment seemed to limit university students to primarily younger Syrian refugees.

Health In all three countries, health insurance was available upon arrival and largely accessible until refugees obtained jobs. Refugees were generally satisfied with the free health care and the level of services provided. This was one realm in which they felt they had equal standing with citizens. One refugee said, "Health insurance is very good in France. Refugees receive a lot of health assistance. The services are very good in France. Everything is secured for daily life."

\section{Social Connection}

Social Bonds Refugees tended to value connectedness to their families and other refugees of like-ethnic groups. Notably, however, refugees described inter-refugee divisions based on differences in their cultural values or experiences in their migration paths. These divisions include differences among old Syrians and newcomers. A refugee in Germany described it as follows:

So we have... newcomers, old immigrants. And there was some kind of, not conflict, not acceptance between both but, no satisfaction in the relationship between those two groups. Those old Syrian immigrants, they felt their situation was threatened in a way. First, they were shocked by the people who are coming. The old Syrian community here, you know how difficult it was for the Syrian to come to Germany or to any European country. So most of those who are here were either doctors, professors, high qualified with high education... 
And then with people coming from lower classes, education or economy. People coming from the rural villages, for them they don't represent Syrians. Those are going to damage our image in the eyes of the Europeans. The other point is there was this kind of maybe jealousy. The old immigrants really suffered here. Suffered to earn their money, suffered to learn the language. There was no integration at that time, who came here 20 years ago, 25 years ago. You have to work, you have to learn, you have to go to college. You have to do everything by your own. They say that now the newcomers are receiving a lot of benefits.

There are differences in the migration patterns among older immigrants and the newcomer community. These have created friction among the two groups and distinct perspectives on integration. Refugees also mentioned distinct perspectives on what women's role should be in the society, including whether they should wear a hijab. Women wearing the hijab faced conflicting pressures from the autochthonous and Syrian community. The autochthonous population excluded women who wear the hijab from all spheres of integration, at the same time some Syrians opposed women giving up the hijab. Refugees mentioned struggling with this pressure to both give up and keep the hijab and the disagreements it created among Syrians. Finally, multiple refugees identified a "religious hardening" that they noticed among particular individuals and ethnic enclaves. As one refugee in France explained:

There is a religious hardening among Syrians in France. Even religiously conservative people are radicalizing in France. Perhaps it is an identity crisis for these religious conservatives. And I think that the percentage of those is great. There is tax evasion within the Syrian community, but this is not limited to the Syrians only. Everyone evades, even the French.

Refugees identified that this hardening of cultural norms was likely an attempt to disrupt the notion of assimilation and remain connected to one's culture.

Social Bridges The majority of refugees described similar experiences in all three countries with discrimination by those from the autochthonous population. They most frequently noted that discrimination concerned the overgeneralization of stereotypes and religion. An overwhelming portion of refugees described being stereotyped as backward, inferior, terrorists or supporters of the Islamic State ISIS, lazy, job-stealing, criminals, and religiously radical. These characteristics were routinely used to describe masses of refugees from the same population. For example, the actions of one refugee were understood by those of the settled community to represent the inclinations of all the refugees within a community. The overgeneralization and misrepresentation of groups were routinely aided by the media, who tended to speak carelessly about refugees using language that labeled them as monolithic and treated their presence as generally undesirable.

Refugees also experienced discrimination based on religion. Women who wore hijabs were regular targets of racism and xenophobia. One refugee in France described an incident involving a taxi driver: "I was a witness to a discrimination incident of a Muslim girl wearing hijab. The lady wanted to take a taxi to go to 
another city. The taxi driver refused to take the Muslim woman and justified his action by saying that she wore the hijab." Other women described the blatant disregard by neighbors or members of the settled community when they passed them on the sidewalk or sat near them in a bus. The host community members would avoid eye contact and communication and, in some instances, would request women to remove their veil.

When asked about the perpetrators, refugees emphasized that the elderly of the autochthonous population frequently partook in the discrimination, noting that more open to and welcoming of their presence were the younger generation. One elderly woman, according to a refugee, boarded a bus and, finding no vacant seat, demanded that the refugee should give up his seat for her. "You are a stranger. This is my place," she asserted. Elders also voiced their disgust at foreign languages. Broadly, refugees described feeling "hatred" from the elderly residents of the autochthonous community.

Social Links Refugees in all three countries described weak social links based on social service neglect and unfair treatment in employment, housing, language, rights, and citizenship domains. In these domains of integration, social services tended to provide inadequate care and benefits to support refugees' integration. As for helping them integrate into the labor market, refugees identified the neglect within individual government organizations as well as the government system as a whole. The most concerning aspect was the bureaucratic nature of processing residence permit applications. Almost every refugee found the process to be confusing, exhausting, and tedious and that navigating it successfully affected their chances of finding jobs and housing. Government regulations frequently required refugees to secure one application before they could apply for another, delaying the possibility of integration and fatiguing all involved. As a result, refugees were commonly tied up in a bureaucracy, awaiting decisions to move forward with their lives. Many refugees noted that these time frames amounted to "years lost," a waiting period during which meaning was stolen from their lives. Even after receiving residence permits, refugees disagreed with the government about the permits' limitations. Some residence permits in Switzerland and Germany were restrictive of refugees' mobility to other countries, which affected their quality of life. This concern was brought up by every refugee in Switzerland, all of whom mentioned the unfairness of the F-residence type and expressed a strong desire to protest. As a result of these experiences with the government, refugees described weak social links and feelings of helplessness, acknowledging their fate lay in the hands of a system that ignored their needs, excluded them, and diminished their existence.

\section{Facilitators}

Language and Cultural Knowledge Refugees noted the importance of language for integration but described differences in language services provided across the three countries and challenges in committing time to attend these courses. In Germany and Switzerland, refugees described free courses for all levels and showed a general 
satisfaction with the quality of these courses. Nevertheless, refugees in France stated that the courses provided by the government (150-200 h of French) included only a beginner-level foundation. As a result, they reached out to outside centers (e.g., universities, private agencies) to learn the language. In some instances, these centers were not free, which added to their financial burden. Another challenge was finding the time to attend these courses while many were working. Refugees mentioned dropping out of courses because of having to work so that they could provide for their families in Europe and in Syria.

The comparison across cases demonstrated that public led language training in Germany and Switzerland outperformed the minimal public training in France. When refugees were consistently assisted through government services to develop language skills, they satisfyingly provided refugees with language training.

Safety and Stability Refugees described experiences with danger and exploitation both during and following migration. During migration, refugees regularly experienced harsh physical conditions, such as using inflatable boats to cross bodies of water, walking through forests where they experienced assaults by other groups, and being robbed and pummeled in the darkness of the night. Following migration, in the settled community, refugees experienced state-sanctioned abuse by police or members of community as well as psychological distress that resulted in their "hating life." Psychological distress was noted as a regular occurrence for some refugees who recounted periods of total isolation, terror when they walked down a street, or fear and anxiety associated with an inability to meet their needs. This distress was naturally amplified when their children were targeted. Some refugees described situations where their children's safety was used as a form of manipulation and exploitation. Refugees were told that their children would be harmed or detained by federal authorities unless refugees responded in the ways that individuals or agencies demanded. Refugee children were also subjected to discrimination in school settings, where their school mates demeaned and even ostracized them for their refugee status or nationality. One refugee recounted an instance when he was held accountable, in class, for attacks perpetrated against a community (made by other individuals of his nationality), despite the refugee not being involved in the attack.

\section{Foundation}

Rights and Citizenship Refugees struggled to integrate even at a foundational level. A great challenge was gaining access to residence permits that allowed them the freedom to fully integrate into the society. In all three countries, refugees experienced challenges with obtaining permit rights and with the limitations of rights based on a permit type. In France, the government assisted refugees during the process. Nevertheless, the process was laborious and with no shared timeline for when they would receive notification about the outcome of their application.

In Switzerland, the majority of refugees mentioned significant challenges with the type of residence permits they received as it had implications for the permit duration and renewal and family reunification (State Secretariat for Migration SEM, 
2019). The B-residence permit is for officially recognized refugees and issued for one year. It is typically renewed as long as the permit holder is still recognized as a refugee. Recognized refugees are given permission to be joined by their family members who lived as a family unit prior to fleeing their country of origin. These family members are also granted asylum. The F-residence permit is for provisionally admitted foreigners and simply maintains that a person may remain in Switzerland for one year with possible renewal. Those who receive this permit must manage its limitations, primarily as they constrain family reunification. The F permit requires at least a three-year waiting period for provisionally admitted foreigners to be joined by their immediate family members. Further, reunification requires a number of met prerequisite conditions, including suitable housing and financial independence. This type of permit limited refugees' ability to move to new regions in the country and their mobility outside the country. It also limited their ability to sign mobile contracts or rent a home independently. Landlords frequently refused to rent housing to those with this permit type. Some refugees were fortunate to obtain the "good" residence permit (the B-residence permit) if they were able to show "political risks" in Syria. Many were confused about the process of granting one permit type over another. Refugees remarked that the process had no systematic logic and even those who met the requirements (e.g., being wanted by the Syrian regime) were denied approval. Others thought that those with poor language skills and who were unemployed would not receive one.

In Germany, a similar situation was observed where refugees described restricted mobility outside the country based on their residence permit. Permits dictated what refugees were allowed to do and when they were allowed to do it. This is but one example of the state repression experienced by refugees who regularly experienced detainment, pursued by security institutions, and rejections of asylum status. One refugee described his process of migration, which was made overwhelmingly difficult by abuses of power, persecution, state repression, and securitization of borders.

This particular Syrian demonstrated against his country's regime, which got his name on a most-wanted list. Seeking safety, the refugee arranged for a smuggler to transport him to Beirut and then Canada. From Beirut, the refugee's plane stopped in Paris and then went directly to Cuba, where the smuggler told the refugee that he could no longer help due to road closures in Canada. The refugee requested help getting to the Netherlands where friends and family lived. However, without a particular visa, the refugee was forced to return to Paris, where he was arrested for illegally entering the country. The French government tried to force him to apply for asylum. He refused because it required a fingerprint agreement, which would prohibit him from then traveling to the Netherlands. The police detained the refugee and held him at the airport until he agreed to apply for asylum. He then left France and upon arriving in the Netherlands and waiting for months, he saw his application for asylum had been rejected because of the fingerprints taken in France. The refugee hired a lawyer, but to no avail. He was deported to France where he knew no one.

This example represents the tremendous challenges posed by state repression. It is but one of many examples shared by refugees who were essentially homeless and faced insecurity for lengthy periods of time due to the repressive forces of bureaucratic authority. 


\section{Discussion}

In Europe, autochthonous populations often express fear of new minorities and, in particular, refugees (Poushter, 2016). Recent electoral gains by exclusionary nationalists hint at the power of these fears. Italy saw the 2016 election of Matteo Salvini who ran on an anti-immigration platform, pledging to turn away humanitarian rescue ships. France, despite voting against the rightwing nationalist Marine Le Pen, saw the introduction of asylum policies in 2018 that weakened people's rights to appeal, safeguards for those experiencing accelerated asylum procedures, and continued permission to detain migrant children. Displaced by civil war and in the context of xenophobia, our question arises, how are Syrian refugees comparatively experiencing refuge in Europe?

We find that discrimination is indeed widespread across all integration domains in Germany, France, and Switzerland. While the autochthonous population allows refugees to participate economically, politically, and socially, discrimination persists across all of the integration domains and participation remains systematically unequal. The discrimination supports findings of several longitudinal studies that observe low levels of economic integration for refugees in Europe as well as case studies that find repeated barriers to social and political integration, such as marriages and citizenship (Donato \& Ferris, 2020). For instance, refugees may be employed, but do not have access to high-wage jobs or professional positions. Similarly, they may protest and publish newspapers, but do not have the right to vote or have equal access to political levers of power. These findings are particularly important as they demonstrate that participation in various domains is not the same as integration in these domains (Hynie, 2018). Beyond participation, integration necessitates a change in perspective that also encourages inclusion in multiple domains (Moreno-Colom \& De Alós, 2016). Because the discrimination experience is across all domains, it systematically deepens the divide between the autochthonous and newcomer populations. However, the three countries vary in the discriminatory integration experience across housing, language and cultural knowledge, and rights and citizenship integration domains. First, in Germany, refugees struggled to find housing because of the discriminatory practices from landlords. Housing is a precondition to enjoying basic rights and services (Andersen et al., 2013; Netto, 2011; Phillips, 2006); thus, it is an important step to gaining social inclusion. As a result, without a house, a refugee could not begin to feel a sense of home. To secure housing, refugees in Germany were forced to find a sublease or wait for extensive periods. Some refugees had no choice but to live in shelters or move into housing with other refugees in substandard conditions. Finding homes large enough to comfortably accommodate larger families was nearly impossible. In urban areas, refugees even without families waited years to secure housing. In other words, these refugees went years with no opportunity to look like, or feel included with, the vast majority of those living in the country possessing regular shelter. Second, in France, language courses kept refugees from gaining language competency; one of the most vital factors for establishing a sense of belonging in a new society. Language proficiency is also critical for employment and social connections (Kristjansdottir \& Skaptadottir, 
2018). While providing language courses is not always sufficient to ensure language proficiency as many refugees worked and were not available to attend them, free access in Switzerland and Germany provided more opportunities to refugees compared to refugees in France. In particular, because France provided only beginner level language study, refugees mentioned additional barriers in accessing language and cultural opportunities. They had to reach out to other centers or universities to find language course and experienced an additional burden to integration. Third, in Switzerland, F-residence permits significantly restricted refugees' rights (Kiselev et al., 2020). The residence permit restricted their mobility as well as their ability to sign mobile contracts or rent a home independently. Additionally, the two types of residence permits created confusion regarding who gets the "good" or "bad" residence permits. The decisions were not viewed to have a systematic logic which increased the level of uncertainty in refugees' everyday life. The restrictive nature of residency permits is well correlated with restrictions on rights and amounts to increasing stratification within the society (Kiselev et al., 2020; Zetter \& Ruaudel, 2014; Morris, 2002).

The contrasting differences across experiences in integration domains in the three countries outline the types of social programs and legal rights that significantly inhibited or enhanced integration. Particularly, in the housing domain, these findings show that as the autochthonous population frequently discriminates the Syrian population, private and personal decision making needs to be removed from housing allocation decisions. When refugee housing is orchestrated by private individuals and companies it is repeatedly found to lead to discriminatory practices (Gardesse \& Lelevrier, 2021; Hanhörster \& Lobato, 2021). Social programs run by government with democratic oversight better assured housing for all refugees and provided more security and safety. In the language and cultural knowledge domain, the findings confirm the importance of social programs aimed at language proficiency (Isphording, 2015). Since language is a critical component for all integration domains, it needs to be provided effectively. In both Germany and Switzerland, the governments provided extensive free language training, and refugees felt satisfied by the opportunities to learn the language. In France, where public language training was only at the beginner level, and higher levels left to private services, refugees cited frequent frustrations. This provides further evidence in support of government led refugee integration. In the rights and citizenship domain, the findings outline the challenges of basic political freedoms. Without equality before the law refugees will continue to feel the burden and looming threat of insecurity that comes with statelessness (Gibson et al., 2016; Wooding, 2008), the findings in this article reinforce the call for both the international community and states to guarantee refugee rights.

The variation in problematic domains followed a simple pattern of democratic government involvement. In each country, the most problematic domain arose where the government largely outsourced implementation and had limited reach or limited democracy. While the private sector has worked well in providing refugee services in North America, it shows challenges in two of the four integration framework factors - Markers and Means and Facilitators - in Europe. In Switzerland, France, and Germany, the private sector has little incentive to take actions necessary for providing effective integration, like creating comprehensive services that can 
address multiple integration needs and provide flexible and personalized services (Hohm et al., 1999). Traditional welfare states, like many in Europe, have developed government programs for serving vulnerable populations, which translate into the public sector being best prepared and most agile in effectively serving refugees (van Selm, 2003). With added democratic oversight holding government providers accountable, public sector services adapt to meet the needs of a changing population (Feinstein, 2019). Switzerland is not a traditional welfare state, but the state is similar to Germany in not outsourcing most refugee services (Lethbridge, 2017). By comparison, the United States (US), another not a traditional welfare state, relies primarily on the private sector to develop programs for serving vulnerable populations and the public sector takes a minimal role. In part, weak political parties in the US have been unable to develop democratic involvement in state welfare programs, leaving market forces to commodify these programs. Research confirms that these US private sector programs perform well in refugee employment (van Selm, 2003). This finding should not discourage changing the historic patterns of service providers, but identifies a systematic deprivation in services provided by the private sector in European welfare states and, if a change is not made, to utilize democratic public agencies, to highlight the deep need for improvement among the private sector. The more immediate concern of this research draws our attention to sites and providers where vulnerable communities are currently not being effectively served.

\section{Conclusions}

Syrian refugees in Europe continue to encounter challenges regarding integration. This research identified the challenges to integration in diverse domains including those that act as markers and means (employment, housing, education and health), social connections (social bonds, social bridges and social links), facilitators (language and cultural knowledge, safety and stability), and foundations (rights and citizenship) of integration. Using 58 interviews with Syrian refugees living in Germany, France, and Switzerland, the research team found out that refugees are marginalized and excluded from all domains of integration. Despite discrimination in all integration domains, countries vary in which domains and indicators pose the greatest challenges to refugees. In Germany, refugees frequently encountered obstacles to finding adequate housing. In France, refugees often struggled to obtain adequate language training, and in Switzerland, refugees encountered anxiety and uncertainty applying for residence permits as the process seemed to lack transparency. We found that when governments outsourced integration efforts in a domain and had less involvement or democractic processes in the domain, refugees identified the domain as posing the most frequent challenge to integration. Comparatively, when the government did not outsource integration efforts in the domain and remained actively involved or more democratic in the process, refugees did not identify discrimination in the domain as posing the greatest challenge. 


\section{Appendix}

Table 3 Average cost of apartment rental

\begin{tabular}{|c|c|c|c|c|c|}
\hline \multirow[b]{2}{*}{ Country } & \multirow[b]{2}{*}{ City } & \multicolumn{2}{|c|}{ Inside city center } & \multicolumn{2}{|c|}{ Outside city center } \\
\hline & & $\begin{array}{l}1 \text { Bedroom } \\
\text { (Euro/month) }\end{array}$ & $\begin{array}{l}3 \text { Bedroom } \\
\text { (Euro/month) }\end{array}$ & $\begin{array}{l}1 \text { Bedroom } \\
\text { (Euro/month) }\end{array}$ & $\begin{array}{l}3 \text { Bedroom } \\
\text { (Euro/month) }\end{array}$ \\
\hline \multirow[t]{3}{*}{ Germany } & Berlin & 954 & 1904 & 670 & 1268 \\
\hline & Essen & 533 & 1025 & 403 & 880 \\
\hline & Bochum & 513 & 900 & 384 & 710 \\
\hline Switzerland & Zurich & 1894 & 3522 & 1342 & 2489 \\
\hline \multirow[t]{2}{*}{ France } & Reims & 517 & 1300 & 535 & 1043 \\
\hline & Paris & 1215 & 2731 & 876 & 1812 \\
\hline
\end{tabular}

Numbeo, 2021

Acknowledgements The authors would like to thank Yousif Shekho and Qusay Sheikho for their insights and help with data collection. They would also like to express their special thanks to all the interviewees. We hope we do your stories and knoweldge justice. Thank you for entrusting us.

\section{Declarations}

Conflict of Interest The authors declare no competing interests.

Open Access This article is licensed under a Creative Commons Attribution 4.0 International License, which permits use, sharing, adaptation, distribution and reproduction in any medium or format, as long as you give appropriate credit to the original author(s) and the source, provide a link to the Creative Commons licence, and indicate if changes were made. The images or other third party material in this article are included in the article's Creative Commons licence, unless indicated otherwise in a credit line to the material. If material is not included in the article's Creative Commons licence and your intended use is not permitted by statutory regulation or exceeds the permitted use, you will need to obtain permission directly from the copyright holder. To view a copy of this licence, visit http://creativecommons.org/licen ses/by/4.0/.

\section{References}

Andersen, Hans Skifter, Turner, Lena Magnusson, \& Soholt, Susanne (2013). The special importance of housing policy for ethnic minorities: Evidence from a comparison of four nordic countries. International Journal of Housing Policy, 13(1), 20-44. https://doi.org/10.1080/14616718.2013.764659

Andersson, R., Musterd, S., \& Galster, G. (2018). Port-of-entry neighborhood and its effects on the economic success of refugees in Sweden. International Migration Review, 53(3), 671-705.

Ager A, Strang A (2004) Indicators of integration: Final Report.' Home Office Development and Practice Report 28. London: Home Office. http://webarchive.nationalarchives.gov.uk/20110218135832/ http:/rds.homeoffice.gov.uk/rds/pdfs04/dpr28.pdf

Ager, A., \& Strang, A. (2008). Understanding integration: A conceptual framework. Journal of Refugee Studies, 21(2), 166-191. https://doi.org/10.1093/jrs/fen016

Ager, A. (2014). Health and forced migration. The Oxford handbook of refugee and forced migration studies, 433-446. 
Akcapar, Sebnem Koser, and Dogus Simsek. (2018). "The politics of Syrian refugees in Turkey: A question of inclusion and exclusion through citizenship." Social Inclusion 6 (1): 176-87. https://doi.org/ 10.17645/si.v6i1.1323

Asylum Information Database (AID). (2021). May 14. Social welfare: Switzerland. https://asylumineu rope.org/reports/country/switzerland/content-international-protection/s

Baban, F., Ilcan, S., \& Rygiel, K. (2017). Syrian refugees in Turkey: Pathways to precarity, differential inclusion, and negotiated citizenship. Journal of Ethnic and Migration Studies, 43(1), 41-57.

Bakker, L., Cheung, S. Y., \& Phillimore, J. (2016). The asylum-integration paradox: Comparing asylum support systems and refugee integration in the Netherlands and the UK. International Migration, 54(4), 118-132.

Bakker, L., Dagevos, J. \& Engbersen, G. (2014). The importance of resources and security in the socioeconomic integration of refugees. A study on the impact of length of stay in asylum accommodation and residence status on socio-economic integration for the four largest refugee groups in the Netherlands. Int. Migration \& Integration 15, 431-448 (2014). https://doi.org/10.1007/ s12134-013-0296-2

Barbosa, A. S. P., Jovanovic, B., \& Spiegel, M. M. (1997). Intequality and stability. Annales D'economie Et De Statistique, 48, 15-40. https://doi.org/10.2307/20076095

Barone, Carlo \& Van De Werfhorst, Herman G. (2011). Education, cognitive skills and earnings in comparative perspective. International Sociology, 26(4), 483-502. https://doi.org/10.1177/0268580910 393045.

Beiser, Morton (2009). Resettling refugees and safeguarding their mental health: Lessons learned from the Canadian Refugee Resettlement Project. Transcultural Psychiarty. https://doi.org/10.1177/ 1363461509351373

Beiser, M., \& Wickrama, K. A. S. (2004). Trauma, time and mental health: A study of temporal reintegration and depressive disorder among Southeast Asian Refugees. Psychological Medicine, 34(5), 899-910. https://doi.org/10.1017/S0033291703001703

Bermúdez, Sandra (2020) Refugees welcome? Cross-European public opinion on asylum seekers following the 2015 crisis Real Insituto elcano Royal institute Accessed: http://www.realinstitutoel cano.org/wps/wcm/connect/a1246cdd-37b8-4747-aa41-c81fe0013d32/ARI119-2020-BermudezRefugees-welcome-Cross-European-public-opinion-on-asylum-seekers-following-2015-crisis.pdf? MOD=AJPERES \&CACHEID=a1246cdd-37b8-4747-aa41-c81fe0013d32

Berry, J. W. (1992). Acculturation and adaptation in a new society. International Migration, 30, 69.

Berry, J. W. (2011). Integration and multiculturalism: Ways towards social solidarity. Papers on Social Representations, 20(1), 2-1.

Bevelander, Pieter. (2016). Integrating refugees into labor markets: Economic integration of refugees into their host country is important and benefits both parties. IZA World of Labor 269:1-9. Available from https://wol.iza.org/articles/integrating-refugees-into-labor-markets/long

Beversluis, D., Schoeller-Diaz, D., Anderson, M., Anderson, N., Slaughter, A., \& Patel, R. B. (2016). Developing and validating the refugee integration scale in Nairobi. Kenya. Journal of Refugee Studies, 30(1), 106-132.

Blight, K.J., Ekblad, S., Persson, J., Ekberg, J. (2006). Mental health, employment and gender. Crosssectional evidence in a sample of refugees from Bosnia-Herzegovina Living in Two Swedish Regions. Social Science \& Medicine 62(7), 1697-1709.

Bloch, Alice (2004). Making it Work: Refugee Employment in the UK. (Asylum and Migration Working Paper; No. 2). https://www.research.manchester.ac.uk/portal/alice.bloch.html

Boateng, A. (2010). Survival voices: Social capital and the well-being of liberian refugee women in Ghana. Journal of Immigrant and Refugee Studies, 8(4), 386-408.

Borselli, M., \& van Meijl, T. (2020). Linking migration aspirations to integration prospects: The experience of syrian refugees in Sweden. Journal of Refugee Studies. https://doi.org/10.1093/ jrs/feaa043

Buscher, Dale (2011). New approaches to urban refugee livelihoods. Refugee, 28(2), 17-29. https:// doi.org/10.25071/1920-7336.36473

Cheung, S. Y., \& Phillimore, J. (2014). Refugees, social capital, and labour market integration in the UK. Sociology, 48(3), 518-536.

Chiswick, Barry R. \& Miller, Paul W. (1999). Language skills and earnings among legalized aliens. Journal of Population Economics, 12(1), 63-89. https://doi.org/10.1007/s001480050091

Cloke, Paul, Crang, Philip, \& Goodwin, Mark (2005). Introducing Human Geographies (2 ${ }^{\text {nd }}$ ed). Hodder Education 
Collier, P., \& Betts, A. (2017). Refuge: Rethinking refugee policy in a changing world. Oxford University Press.

Daley, C. (2007). Exploring community connections: Community cohesion and refugee integration at a local level. Community Development Journal, 44(3), 158-171.

Deacon, Zermarie \& Sullivan, Cris (2009). Responding to the complex and gendered needs of refugee women. Journal of Women and Social Work, 24(3), 272-284. https://doi.org/10.1177/08861 09909337401

Donato, K. M., \& Ferris, E. (2020). Refugee integration in Canada, Europe, and the United States: Perspectives from research. The Annals of the American Academy of Political and Social Science, 690(1), 7-35.

Dumper, Hildegard (2002). Missed opportunities: A skills audit of refugee women in London from the teaching, nursing, and medical professions. London: Greater London Authority. http://dera.ioe.ac. uk/id/eprint/8661

European Council on Refugees and Exiles (ECRE), Good Practice Guide on the Integration of Refugees in the European Union. Health, September 1999, available at: https://www.refworld.org/ docid/4652feff2.html [accessed 19 October 2021]

Expatistan (2021). Cost of living by city. https://www.expatistan.com. Accessed 10 Oct 2021.

Fasani, F., Frattini, T., \& Minale, L. (2018). (The struggle for) refugee integration into the labour market: Evidence from Europe. Centro Studi Luca d'Agliano Development Studies Working Paper, (435).

Feinstein, S. G. (2019). When informal institutions change: Institutional reforms and informal practices in the Former Soviet Union. By Huseyn Aliyev. Ann Arbor: University of Michigan Press, 2017. 296p. \$80.00 cloth. Perspectives on Politics, 17(2), 613-615. https://doi.org/10.1017/S153759271 9000446

Feinstein, S., \& Poleacovschi, C. (2021). Making democracy work in a refugee camp: Social capital and the emergence of empowerment. Development in Practice, 1-13. https://doi.org/10.1080/09614524. 2021.1937558

Fennelly, K., \& Palasz, N. (2003). English language proficiency of immigrants and refugees in the Twin Cities metropolitan area. International Migration, 41(5), 93-125.

Fiddian-Qasmiyeh, E., Loescher, G., Long, K., \& Sigona, N. (Eds.). (2014). The Oxford handbook of refugee and forced migration studies. OUP Oxford.

Gardesse, C., \& Lelévrier, C. (2020). Refugees and asylum seekers dispersed in non-metropolitan French cities: Do housing opportunities mean housing access?. Urban planning.

Gibson, T., James, H., \& Falvey, L. (Eds.). (2016). RohingyasInsecurity and Citizenship in Myanmar: Insecurity and Citizenship in Myanmar. Thaksin University Press.

Grace, B. L., Nawyn, S. J., \& Okwako, B. (2018). The right to belong (if you can afford it): Market-based restrictions on social citizenship in refugee resettlement. Journal of Refugee Studies, 31(1), 42-62. https://doi.org/10.1093/jrs/few046

Gracia, P., Vazquez-Quesada, L., De Werfhorst, V., \& Herman, G. (2016). ethnic Penalties? The Role of human capital and social origins in labour market outcomes of second-generation Moroccans and Turks in the Netherlands. Journal of Ethnic and Migration Studies, 42(1), 69-87. https://doi.org/ 10.1080/1369183X.2015.1085800

Grüttner, M., Berg, J., Schröder, S., \& Otto, C. (2018). Refugees on their way to German higher education: A capabilities and engagements perspective on aspirations, challenges and support. Global Education Review, 5(4), 115-135.

Harrell-Bond (1986). Imposing aid: Emergency assistance to refugees. Oxford University Press.

Hairo, A., Stahl, G. K., Clegg, C. C., \& Lazarova, M. B. (2019). Acculturation, coping, and integration success of international skilled migrants: An integrative review and multilevel framework. Human Resource Management Journal., 29, 328-352.

Hart, J. (2014). Children and forced migration. The Oxford handbook of refugee and forced migration studies, 383-394.

Hatoss, A. (2012). Where are you from? Identity construction and experiences of 'othering' in the narratives of Sudanese Refugee-Background Australians. Discourse \& Society, 23(1), 47-68. https://doi. org/10.1177/0957926511419925

Hanhörster , H \& Ramos Lobato , I (2021), ' Migrants' access to the rental housing market in Germany: Housing providers and allocation policies ', Urban Planning, vol. 6 , no. 2 , pp. 7-18. https://doi. org/10.17645/up.v6i2.3802 
Heckmann, Friedrich and Dominique Schnapper (2016) The integration of immigrants in European societies: National differences and trends of convergence. De Gruyter Oldenbourg

Hodali, D., \& Prange, A. (2018). Asylum benefits in the EU: How member states compare. Retrieved February, 19, 2019.

Hogg, M. A. (2006). Social Identity Theory. In P. J. Burke (Ed.), Contemporary social psychological theories (pp. 111-136). Stanford University Press.

Hohm, C. F., Sargent, P., \& Moser, R. (1999). A quantitative comparison of the effectiveness of public and private refugee resettlement programs: An evaluation of the San Diego Wilson Fish Demonstration Project. Sociological Perspectives, 42(4), 755-763.

Hos, Rabia (2020). The Lives, aspirations, and needs of refugee and immigrant students with Interrupted Formal Education (SIFE) in a Secondary New Comer Program. Urban Education, 55(7), 10211044. https://doi.org/10.1177/0042085916666932

Hynie, Michaela (2018). "Refugee integration: Research and policy." Peace and Conflict: Journal of Peace Psychology, 24 (3) 265-276.

Ilgit, Asli and Audie Klotz. (2018). "Refugee rights or refugees as threats? Germany's new Asylum policy" British journal of politics \& international relations 20 (3), 613-631

Isphording, I. E. (2015). What drives the language proficiency of immigrants?. IZA World of Labor.

Jacobsen, K. (2006). Refugees and asylum seekers in urban areas: A livelihoods perspective. Journal of Refugee Studies, 19(3), 273-286. https://doi.org/10.1093/jrs/fel017

Jackson, S., \& Bauder, H. (2013). Neither temporary, nor permanent: The precarious employment experiences of refugee claimants in Canada. Journal Fo Refugee Studies, 27(3), 360-381. https://doi.org/ $10.1093 / \mathrm{jrs} / \mathrm{fet} 048$

Kaida, L., Hou, F., \& Stick, M. (2020). The long-term economic integration of resettled refugees in Canada: A comparison of Privately Sponsored Refugees and Government-Assisted Refugees. Journal of Ethnic and Migration Studies, 46(9), 1687-1708.

Kawachi, I. (2006). Commentary: Social capital and health: Making the connections one step at a time. International Journal of Epidemiology, 35(4), 989-993.

Keller, A., Lhewa, D., Rosenfeld, B., Sachs, E., Aladjem, A., Cohen, I., Smith, H., \& Porterfield, K. (2006). Traumatic experiences and psychological distress in an urban refugee population seeking treatment services. The Journal of Nervous and Mental Disease, 194(3), 188-194.

Kiselev, N., Pfaltz, M., Schick, M., Bird, M., Pernille, H., Sijbrandij, M., de Graaff, A. M., Schnyder, U., \& Morina, N. (2020). Problems faced by Syrian refugees and asylum seekers in Switzerland. Swiss medical weekly, 150, w20381.

Knipscheer, J., Sleijpen, M., Mooren, T., Heide, F. J., \& June ter, Aa, Niels van der. (2015). Trauma exposure and refugee status as predictors of mental health outcomes in treatment-seeking refugees. $B J$ Psych Bulletin, 39(4), 178-182.

Kristjansdottir, Erla S. \& Dis Skaptadottir, Unnur (2018). "I'll Always Be a Refugee." The Lived Experiences of Palestinian Refugee Women of Moving to a Small Society in Iceland. Journal of Immigrant and Refugee Studies. https://doi.org/10.1080/15562948.2018.1499065

Kuhlman, T. (1991). The economic integration of refugees in developing countries: A research model. Journal of Refugee Studies, 4(1), 1-29. https://doi.org/10.1093/jrs/4.1.1

Landau, Loren B. (2006). Protection and dignity in Johannesburg: Shortcomings of South Africa's Urban Refugee Policy. Journal of Refugee Studies, 19(3). https://doi.org/10.1093/jrs/fel012.

Lethbridge, Jane (2017) Privatisation of Migration \& Refugee Services \& Other Forms of State Disengagement. European Public Service Union. Public Services International

Lindert, J., Schouler-Ocak, M., Heinz, A., \& Priebe, S. (2008). Mental health, health care utilisation of migrants in Europe. European Psychiatry, 23(S1), s114-s120. https://doi.org/10.1016/S09249338(08)70057-9

Luik, M.-A., Emilsson, H., \& Bevelander, P. (2018). The male immigrant-native employment gap in Sweden: Migrant admission categories and human capital. Journal of Population Research, 35, 363-398.

Matlin, Stephen A., Depoux, Anneliese, Schutte, Stefanie, Flahault, Antoine, Saso, Luciano. (2018). Migrants' and refugees' health: Towards an agenda of solutions. Public Health Reviews 39 (27). Available from https://doi.org/10.1186/s40985-018-0104-9

Marko, V., \& Bunar, N. (2010). State assisted integration: Refugee integration policies in Scandinavian Welfare States: The Swedish and Norwegian Experience. Journal of Refugee Studies., 23(4), 463483. https://doi.org/10.1093/jrs/feq028 
McBrien, J. L. (2005). Educational needs and barriers for refugee students in the United States: A review of the literature. Review of Educational Research, 75(3), 329-364.

McKay, S., Dhudwar, A., \& El Zailaee, S. (2006). Compacting the labor market experiences of refugee and ethnic minorities. Working Lives Research Institute.

McMichael, C., \& Manderson, L. (2004). Somali networks and social capital among immigrant women in Australia. Human Organization, 63(1), 88-99. https://doi.org/10.17730/humo.63.1.nwlpjdj4d4 197561

Mestheneos, E., \& Ioannidi, E. (2002). Obstacles to refugee integration in the European Union Member States. Journal of Refugee Studies, 15(3), 304-320. https://doi.org/10.1093/jrs/15.3.304

Mirza, Mansha . (2012). Occupational upheaval during resettlement and migration: Findings of global ethnography with refugees with disabilities. OTJR: Occupation, Participation and Health 32 (1): S6-S14.

Mollica, Richard F., Poole, Charles, Son, Linda, Murray, Caroline C., \& Tor, Svang (1997). Effects of war trauma on Cambodian refugee adolescents' functional health and mental health status. Journal of the American Academy of Child \& Adolescent Psychiatry, 36(8), 1098-1106. https://doi.org/10. 1097/00004583-199708000-00017

Moreno-Colom, S., \& De Alós, R. (2016). La inmigración en España:¿ Una integración con pies de barro?. Política y sociedad, 53(2), 509-528. Morris, L. (2003). Managing migration: Civic stratification and migrants rights. Routledge.

Morris, L. (2003). Managing migration: Civic stratification and migrants rights. Routledge.

Mosselson, J., Morshed, M. M., \& Changamire, N. (2017). Education and wellbeing for refugee youth. Peace Review: A Journal of Social Justice, 29, 15-23. https://doi.org/10.1080/10402659.2017. 1272281

Murdie, R., \& Ghosh, S. (2010). Does spatial concentration always mean a lack of integration? Exploring ethnic concentration and integration in Toronto. Journal of Ethnic and Migration Studies, 36(2), 293-311.

Nelson-Peterman, J. L., Toof, R., \& Liang, S. L. (2015). Long-term refugee health: Health behaviors and outcomes of Cambodian refugee and immigrant women. Health Education \& Behavior, 42(6), $814-823$.

Netto, G. (2011). Identity negotiation, pathways to housing and "place": The experience of refugees in Glasgo. Housing, Theory, and Society, 28(2), 123-143. https://doi.org/10.1080/14036096.2010. 503676

Newbold, B., \& McKeary, M. (2016). Investigating the diversity of Canada's refugee Population and its health care implications: Does one size fit all? International Journal of Iteration, Health, and Social Care, 13(2), 145-156. https://doi.org/10.1108/IJMHSC-02-2015-0007

Numbeo (2021). Cost of living in Bochum. https://www.numbeo.com/

OECD (2016) Making integration work, refugees and others in need of protection, OECD report.

OECD (2021) Unemployment rate (indicator). doi: https://doi.org/10.1787/52570002-en

O’Neill, Jim (2001). Building Better Global Economic BRICs. Global Economics Paper 66. New York: Goldman-Sachs. http://www.elcorreo.eu.org/IMG/pdf/Building_Better_Global_Economic_Brics. pdf

Pedersen, M. Holm (2012). Going on a class journey: The inclusion and exclusion of Iraqi refugees in Denmark. Journal of Ethnic and Migration Studies, 38(7), 1101-1117 https://doi.org/10.1080/ $1369183 \mathrm{X} / 2012.681453$

Phillimore, J., \& Goodson, L. (2008). Making a place in the global city: The relevance of indicators of integration. Journal of Refugee Studies, 21(3), 305-325.

Phillimore, J. (2020). Refugee-integration-opportunity structures: Shifting the focus from refugees to context. Journal of Refugee Studies. https://doi.org/10.1093/jrs/feaa012

Phillips, D. (2006). Moving towards integration: The housing of asylum seekers and refugees in Britain. Housing Studies, 21(4), 539-555. https://doi.org/10.1080/02673030600709074

Platts-Fowler, D., \& Robinson, D. (2015). A place for integration: Refugee experiences in two English cities. Population, Space, and Place, 21(5), 476-491. https://doi.org/10.1002/psp.1928

Poortinga, W. (2012). Community resilience and health: The role of bonding, bridging, and linking aspects of social capitol. Health and Place, 18, 286-295. https://doi.org/10.1016/j.healthplace. 2011.09.017

Poushter, Jacob (2016). "European opinions of the refugee crisis in 5 charts." September 16. Pew Research Center 
Puma, J. E., Lichtenstein, G., \& Stein, P. (2018). The Rise survey: Developing and implementing a valid and reliable quantitative measure of refugee integration in the United States. Journal of Refugee Studies, 31(4), 605-625.

Robila, Mihaela (2018). Refugees and Social Integration in Europe. Retrieved from United Nations Department of Economic and Social Affairs (UNDESA) Division for Social Policy and Development

Sasse, G. (2005). Securitization or securing rights? Exploring the conceptual foundations of policies towards minorities and migrants in Europe. JCMS: Journal of Common Market Studies, 43(4), 673-693.

Scheibelhofer, P. (2017). 'It Won't Work without Ugly Pictures': Images of othered masculinities and the legitimisation of restrictive refugee-politics in Austria. NORMA, 12(2), 96-111. https://doi.org/10. $1080 / 18902138.2017 .1341222$

Sigona, N. (2014). The politics of refugee voices: Representations. The Oxford handbook of refugee and forced migration studies, 369-382.

Silove, Derrick, Steel, Zachary, Bauman, Adrian, Chey, Tien, \& McFarlane, Alexander (2007). Social Psychiatry and Psychiatric Epidemiology, 42(6), 467-476. https://doi.org/10.1007/ s00127-007-0194-z

Sim, R. (2016). Into the mind of the refugee: Unpacking modern refugee mental health. Harvard International Review, 37(4), 46-48.

Şimşek, D. (2018). Integration processes of Syrian refugees in Turkey: 'Class-based integration.' Journal of Refugee Studies. https://doi.org/10.1093/jrs/fey057

Sinnerbrink, I., Silove, D., Field, A., Steel, Z., \& Manicavasager, V. (1997). Compounding of premigration trauma and postmigration stress in asylum seekers. The Journal of Psychology, 131(5), 463470. https://doi.org/10.1080/00223989709603533

Shiraz, M., \& Cayman, K. (2016). A narrative account of the life experiences of Somali Refugee Women. The Open Family Studies Journal, 8(1), 21-26. https://doi.org/10.2174/1874922401608010021

State Secretariat for Migration SEM. (2019). Informationsbroschüre des SEM für Flüchtlinge und vorläufig Aufgenommene. https://www.sem.admin.ch/sem/de/home/publiservice/publikationen.html\#659243951. Accessed 21 Sept 2021.

Strang, A., \& Ager, A. (2010). Refugee integration: Emerging trends and remaining agendas. Journal of Refugee Studies, 23(4), 589-607. https://doi.org/10.1093/jrs/feq046

Stephan, W. G. and Stephan, C. W. (2000) 'An Integrated Threat Theory of Prejudice'. In Oskamp, S. (ed.) Reducing prejudice and discrimination. Mahwah, NJ: Erlbaum, pp. 23-45

Szreter, S., \& Woolcock, M. (2004). Health by association? Social capital, social theory, and the political economy of public health. International Journal of Epidemiology, 33(4), 650-667. https://doi.org/ 10.1093/ije/dyh013

Takeda, J. (2000). Psychological and economic adaptation of Iraqi adult male refugees. Journal of Social Service Research, 26(3), 1-21.

Lindert, Te., Annet, K., Hubert, V., de Vijver, F. J. R., Kroon, S., \& Arends-Toth, J. (2008). Perceived discrimination and acculturation among Iranian refugees in the Netherlands. International Journal of Intercultural Relations, 32, 578-588.

Tomlinson, F. (2010). Making difference and negotiating belonging: Refugee women, volunteering and employment. Gender, Work, and Organization, 17(3), 278-296. https://doi.org/10.1111/j. 1468-0432.2008.00399.x

Tippens, J. A. (2019). Urban Congolese refugees' social capital and community resilience during a period political violence in Kenya: A qualitative study. Journal of Immigrant and Refugee Studies. https://doi.org/10.1080/15562948.2019.1569744

Tubergen, Frank van \& Kalmijn, Matthijs (2005). Destination-language proficiency in cross-national perspective: A study of immigrant groups in nine western countries. AJS, 110(5), 1412-1457. https://doi.org/10.1086/428931

UNHCR (2019). UNRWA through UNHCR's Refugee Data Finder at unhcr.org/refugee-statistics

Valenta, M., \& Bunar, N. (2010). State assisted integration: Refugee integration policies in Scandinavian welfare states: The Swedish and Norwegian experience. Journal of Refugee Studies, 23(4), 463-483.

Valtonen, K. (2008). Social Work and Migration: Immigrant and Refugee Settlement. Routledge. https://doi.org/10.1177/00208728100530041003 
van Heelsum, A. (2017). Aspirations and frustrations: Experiences of recent refugees in the Netherlands. Ethnic and Racial Studies, 40(13), 2137-2150. https://doi.org/10.1080/01419870.2017. 1343486

Van Selm, J. (2003). Public-private partnerships in refugee resettlement: Europe and the US. Journal of International Migration and Integration/revue De L'integration Et De La Migration Internationale, 4(2), 157-175.

Wachter, Karin, Heffron, Laurie Cook, Snyder, Susanna, Nsonwu, Maura Busch, \& Busch-Armendariz, Noel Bridget (2016). Unsettled integration: Pre - and post - migration factors in Congolese Refugee women's resettlement experiences in the United States. International Social Work, 59(6), 875-889. https://doi.org/10.1177/0020872815580049

Ward, M., Poleacovschi, C., Faust, K., Weems, C. F., Gabiam, N. (2020). Evaluating the role of infrastructure components and demographics on social capital in refugee camps. Journal of Management in Engineering 36 (3): 04020007. https://doi.org/10.1061/(ASCE)ME.1943-5479.0000754

Wauters, D. B., \& Lambrecht, P. D. J. (2008). Barriers to refugee entrepreneurship in Belgium: Towards an explanatory model. Journal of Ethnic and Migration Studies, 34(6), 895-915. https://doi.org/10.1080/13691830802211190

Whittaker, Sara, Hardy, Gillian, Lewis, Kathryn, \& Buchan, Linda (2005). An exploration of psychological well-being with young Somali refugee and asylum-seeker women. Clinical Child Psychology and Psychiatry, 10(2), 177-196. https://doi.org/10.1177/2F1359104505051210

Wijbrandi, J. B. (1986). Organized and spontaneous settlement in Eastern Sudan: Two case studies on integration of rural refugees. Free University, Faculty of Economics, Department of Development Studies.

Wijers, G. D. M. (2013). Immigrant communities as resources for emancipation: A comparison of bounded solidarity in two Cambodian communities. Migration and Development, 2, 74-92.

Wooding, B. (2008). Contesting Dominican discrimination and statelessness. Peace Review, 20(3), 366-375.

Woolcock, M. (2002). Social capital in theory and practice: Where do we stand. Social Capital and Economic Development: Well-Being in Developing Countries, 1(2), 18-39.

Zetter, R., \& Ruaudel, H. (2014). Development and protection challenges of the Syrian refugee crisis. Forced Migration Review, 47, 6.

Zhou, M., \& Bankston, C. L., III. (1998). Growing up American: The adaptation of Vietnamese adolescents in the United States. Russell Sage Foundation.

Publisher's Note Springer Nature remains neutral with regard to jurisdictional claims in published maps and institutional affiliations. 